\title{
Sports tourism and new opportunities in developing countries: A case study of sport tourism in the province of Ardebil
}

\author{
Abolfazl A. Tajzadeh Namin ${ }^{\mathrm{a}^{*}}$ and Kambiz Niknam ${ }^{\mathrm{b}}$
}

${ }^{a}$ Faculty of Management and Accounting, Allameh Tabataba'i University, Tehran, Iran

${ }^{b}$ Master of Tourism Management

\begin{tabular}{l}
\hline A R T I C L E I N F O \\
\hline Article history: \\
Received July 20, 2011 \\
Received in Revised form \\
October, 12, 2011 \\
Accepted 15 October 2011 \\
Available online \\
30 October 2011 \\
\hline Keywords: \\
Sport tourism \\
Tourism industry \\
Water treatment \\
Hiking
\end{tabular}
\begin{abstract}
A B S T R A C T
Sport tourism plays an important role on developing economy and it can create tremendous opportunities for developing non-industrial regions. It is also the fastest growing sector in the global travel industry and generates hundreds of billions of dollars per year. The proposed study of this paper surveys different factors influencing sport tourist activities. The study distributes a questionnaire among 100 randomly chosen tourists in the province of Ardebil, Iran and the results are analyzed. The results indicate that Cronbach Alpha is 87.7 percents, which validates the reliability of our results. Based on the results, the region has tremendous opportunities for sport tourism such as water treatment. There are other opportunities in the province such as beautiful nature, historical monuments, mountains, etc. Unfortunately, the survey reveals that people are not aware of these places and governmental media must spend more efforts on introducing these opportunities.
\end{abstract}

(c) 2012 Growing Science Ltd. All rights reserved.

\section{Introduction}

sport tourism involves either viewing or taking part in a sporting event staying apart from the usual environment. Sport Tourism is the fastest growing sector in the global travel industry and equates to hundreds of billions a year (Plog, 1991; World Tourism Organization, 1997; Zhang et al., 1996). According to Gammon and Robinson (2003) sports tourism can be categorized as hard and soft tourism, while Gibson (2006) and Gibson and Yiannakis (1998) reported three types of sports tourism including sports event tourism, celebrity and nostalgia sport tourism and active sport tourism.

Hard definition of sport tourism is associated with the frequency of people taking part in competitive sport events. Normally these kinds of events create more motivations for visitors to visit the events. Examples of hard sport include Olympic Games, FIFA World Cup, etc. These sporting activities are part of the wider and growing analysis of major events within diverse fields of urban regeneration, economic development, politics and tourism (Getz, 1997). Hard sporting events are justified, in terms of the public cost, which is needed to host them, on the basis of their long-term advantages through

* Corresponding author. +989122489294

E-mail addresses: ardehshir tajzadeh-namin <tajzadehnamin@yahoo.com> 
new event and urban infrastructure, urban renewal, enhanced international reputation, increased tourist visitation and associated benefits. Soft sports are relatively the tourists travel for participating in recreational sporting, or signing up for a leisure interests. Hiking, Skiing and Canoeing are examples of this kind of tourism (Hall, 1992; Hamilton-Smith, 1993).

Devine and Devine (2004) discussed the politics of sport tourism in Northern Ireland. They discussed how politics impinges on policies associated with sport, tourism and consequently sports tourism. They first dealt with the political situation in Northern Ireland and explained how it affected local tourism and sport. Next, they analyzed the tourism potential of local sports and recommended how Northern Ireland's tourism industry could capitalize on a sport, which is unique to the island of Ireland.

A sport product is a good, service or a combination of these two items, which is required to meet sport fans, participants or sponsors. Sport itself is a market and it has both tangible and intangible components, which makes it an exclusive product for marketing (Shank, 2005). According to Kozak (2004), there are four reasons for having a trip including cultural reasons, leisure, rest and physical activities. There are different events, which could attract people for having trips and there are also different reasons, which prevents people for taking part in events such as trouble for getting visa, high expenses of traveling to different locations, etc (Barker et al., 2007). There are varieties of sport trip, which are important and Kurtzman (2005) categorized them as boating, Guelph, Tennis, hunting, etc. Kurtzman and Zauhar (2005) discussed new emerging issues of sport and explained that the new issues could help developing countries.

\section{The proposed framework}

The proposed study of this paper investigates different factors influencing people for participating sport tourism in province of Ardebil located in north-west part of Iran. Ardabil is the center of Ardabil province and according to a census held in 2006, its population was 412,669, in 102,818 families. There are many monuments in this province such as the sanctuary and tomb of Shaikh Safî ad-Dîn, eponym of the Safavid Dynasty. The proposed study of this paper attempts to find different important issues for having sport tourism in this province. We would like to know about people's personal characteristics and their legitimate reasons for having travel to this province. We consider those who take part in different tourism activities in cities of Adebil, Sarein and Meshkin Shahr. The survey covers only internal tourists who have recently participated in one of sport tourism activities. The questionnaire is distributed among 110 people and we end up having 100 filled ones, which are used for this survey. All questions are in Likert (Likert, 1932) based and they are examined using $\chi^{2}$ and binomial tests. The Cronbach Alpha (Cronbach, 1951) was 87.7 percents, which was well above the minimum required level.

The survey reveals that 15 percents people who participated in our survey were less than 20 years old, 56 percents were between 20 to 30 years old and 30 percents were 30 years old or more. In terms of gender, 62 percents of the survey people were male and 38 percents were female. While 54 percents of the participants were single, 46 percents were married. In terms of the number of family members, 54 percents of the survey participants had at least five family members, 16 percents maintained four family members, twenty one percents had three family members and nine percents had only two family members.

In terms of educational background, while 28 percents of the participants did not finish high school, 54 percents finished high school, 9 percents maintained 2 years colleague and nine percents hold bachelor or master degrees. In terms of vehicle, only three percents of the participants used air trip, 34 percents used bus, 55 percents used their own personal car, two percents participated in tour facilities and the remaining six percent used other facilities. According to our survey, only seven 
percent of the trips were held in spring, 42 percent were held in summer, 6 percents of the trips happened during the fall, six percent occurred in winter and season had nothing to do for 32 percent of the people who participated in our survey. In terms of frequency of trips, seven percents of the participants were first time traveler, seventeen percents were the people whose trip was their second experience and 76 percent had, at least, three experience of trip.

\section{The results}

In this section, we present details of our survey results, which include 17 questions. The questions cover different purposes of having sport trip.

\subsection{The purpose of trip}

The first question asks participants on the purposes of their trip, which are visiting their friends and family members, visiting the province, business affairs and other issues. The null hypothesis is that there is no difference between the purpose of trip among participants, which yields $\chi^{2}=24.560$ with three degree of freedom and p-value is 0.000 . Based on the results, the null hypothesis is rejected and there is a tendency among participants for having trip to this province. Table 1 shows the expected and observed data for this question.

\section{Table 1}

The Oi-Ei analysis for the first question

\begin{tabular}{llll}
\hline Question & Observed & Expected & Residual \\
\hline Visiting their friends and family members & 21 & 25 & -4 \\
Visiting the province & 32 & 25 & 7 \\
\hline Business affairs & 7 & 25 & -18 \\
\hline Others & 40 & 25 & 15 \\
\hline Total & 100 & 100 & \\
\hline
\end{tabular}

Based on the results of Table 1, we can conclude that people were mostly interested in visiting the province as well as other purposes.

\subsection{The motivation of having a trip to this province}

The second question seeks on people's motivation for having a trip to this province including visiting the nature, having a calm time, visiting historical monuments, watching the beautiful nature, having more adventure, water treatment and other issues.

Table 2

The Oi-Ei analysis for the second question

\begin{tabular}{lccc}
\hline Question & Observed & Expected & Residual \\
\hline visiting the nature & 23 & 14.28 & 8.72 \\
having a calm time & 21 & 14.28 & 6.72 \\
visiting historical monuments & 16 & 14.28 & 2.72 \\
\hline watching the beautiful nature & 11 & 14.28 & -3.28 \\
Having more adventure & 2 & 14.28 & -12.28 \\
Water treatment & 23 & 14.28 & 9.72 \\
\hline Others & 2 & 14.28 & -12.28 \\
\hline Total & 100 & 100 & \\
\hline
\end{tabular}


The null hypothesis is that there is no difference between different motivations of trip among participants, which yields $\chi^{2}=42.983$ with six degrees of freedom and the p-value is 0.000 . Based on the results, the null hypothesis is rejected and there is a tendency among participants for having trip to this province. Table 2 shows the expected and observed data for this question.

Based on the results of Table 2, one obvious conclusion is that people were mostly interested in visiting the nature of the province, having water treatment, having a good rest and watching historical monuments.

\subsection{The relative importance of exercise in people's lives}

The third question looks for people's interest in regular exercise. Since the responses were in Likert five-scale format, we decided to divide them into two groups of for and against. The null hypothesis is that there is no difference between two groups. Table 3 summarizes the results of our survey.

Table 3

The Oi-Ei analysis for the third question

\begin{tabular}{lccccc}
\hline & Number & Observation & Percent & Test & Significance level \\
\hline Group 1 & $<=3$ & 50 & 0.50 & 0.50 & 1.00 \\
Group 2 & $>3$ & 50 & 0.50 & & \\
\hline Total & & 1.00 & \\
\hline
\end{tabular}

Based on the results, the null hypothesis cannot be rejected and we can conclude that people do not have strong motivation to consider sport as part of their regular activities.

\subsection{The relative importance of exercise in traveling to Ardebil province}

The other important question is whether there is a sport motivation among people for traveling to this province. Table 4 summarizes the results of our survey.

Table 4

The Oi-Ei analysis for the fourth question

\begin{tabular}{lccccc}
\hline & Number & Observation & Percent & Test & Significance level \\
\hline Group 1 & $<=3$ & 60 & 0.60 & 0.50 & 0.57 \\
Group 2 & $>3$ & 40 & 0.40 & & \\
\hline Total & & 1.00 & & \\
\hline
\end{tabular}

Based on the results, the null hypothesis cannot be rejected and we can conclude that people do not have strong motivation to consider sport as the main motivation for having trip to this province.

\subsection{Tourist interest in different exercise}

We have also asked the survey people on their interest in various exercises such as watching sports, taking part in different type of activities, etc. The first question was whether they were interested in watching sport activities and the null hypothesis was that there was no difference between two groups' interest in either watching or not watching sport activities.

The results of our survey yields $\chi^{2}=26.111$ with one degree of freedom and $\mathrm{p}$-value $=0.000$, which means there is a difference between these two groups. The result of binary test also indicated that 27 people were fan of sport activities but 73 people were not and the Oi-Ei statistical test indicates that 
the survey people mainly are not interested in watching sport and exercise events do not play important roles on boosting sport tourism.

In other part of this question, we asked their interest in different types of activities. The frequency of the responses for hiking, biking, horsing and other sport activities were 40,13, 12, 16, 19, respectively. The Oi-Ei statistical test indicates that the survey people mainly are mainly interested in hiking.

The next question of this survey asked people whether they were interested in different types of activities such as ski on water, fishing, boating and other activities. The results of our survey yields $\chi^{2}=10.000$ with three degrees of freedom and $p$-value $=0.000$, which means the null hypothesis of having no difference for people's interest was rejected. The frequency of the responses for ski on water, fishing, boating and other activities were 5, 18, 21, 14, 42, respectively. The Oi-Ei statistical test indicates that the survey people mainly are mainly interested in boating and fishing.

We have also asked our survey people on their interested in different snow based activities such as skiing, snowboarding, sleigh riding and other activities. The results of our survey yields $\chi^{2}=52.11$ with three degrees of freedom and $\mathrm{p}$-value $=0.000$, which means the null hypothesis of having no difference for people's interest was rejected. The frequency of the responses for skiing, snowboarding, sleigh riding and other activities were 38,4, 16, 3, 39, respectively. The Oi-Ei statistical test indicates that the survey people mainly are mainly interested in skiing.

\subsection{Tourist interest in natural attractions}

The province of Ardebil is one of the most beautiful places of Iran with relative low temperature and high level of participation. There are different mountains and rivers in the region, which create tremendous opportunities for camping and other visiting activities. We have asked people whether natural attraction has motivated them for visiting the province or not and the results of our survey strongly recommended that they were strongly interested in visiting the province based on beautiful natural attractions of this region.

\subsection{Tourist interest in weather conditions}

The other question of our survey was associated with people's interest in weather conditions of this province. Our survey did not provide strong evidence to believe that weather conditions could create motivation for people to travel to this province.

\subsection{Tourist interest in domestic athletic people}

One reason for traveling to a place can be associated with the names of the athletic people who live in the area. The province of Ardebil has been the host of some well known athletics such as Rezazadeh and Daee. However, the results of our survey did not provide any evidence to believe that people are interested in traveling to this province because of these people.

\subsection{Tourists interest and their historical exercise experience}

Another question we asked our survey people was whether they had any previous sport experience to create motivation for traveling to this province. Our survey indicated that 54 percent of the people had no previous experience and the results of our statistical test found no evidence to believe having previous experience could encourage people to travel to this province. 


\subsection{Important barriers for sport tourism in province of Ardebil}

One of the most important efforts on boosting sport tourism is to find out the main barriers of developing this industry. We have selected a set of questions and asked the survey people to express their opinions. The results of our survey yields $\chi^{2}=46.308$ with eight degrees of freedom and $\mathrm{p}$ value $=0.000$, which means the null hypothesis of having no influence of different barriers was rejected. Table 5 summarizes the results of our survey in terms of different questions.

\section{Table 2}

The Oi-Ei analysis for different barriers on promoting sport tourism

\begin{tabular}{|c|c|c|c|}
\hline Question & Observed & Expected & Residual \\
\hline Lack of sufficient athletic equipment & 26 & 11.11 & 14.89 \\
\hline Lack of sufficient entertainment equipment & 17 & 11.11 & 5.89 \\
\hline Volatile weather conditions & 12 & 11.11 & 0.89 \\
\hline Long and cold winters & 9 & 11.11 & -2.11 \\
\hline Lack of a good advertisement & 15 & 11.11 & 3.89 \\
\hline Health care condition & 3 & 11.11 & -8.11 \\
\hline Inadequate safety features & 5 & 11.11 & -6.11 \\
\hline Inadequate cooperation among different organizations & 7 & 11.11 & -4.11 \\
\hline $\begin{array}{l}\text { Lack of a good cooperation between governmental athletic } \\
\text { organizations }\end{array}$ & 6 & 11.11 & -5.11 \\
\hline Total & 100 & 100 & \\
\hline
\end{tabular}

The Oi-Ei statistical test indicates that the survey people blame lack of sufficient athletic and entertainment equipments as the most important barriers on developing this industry. The lack of a good information and advertisement and volatile weather conditions are other important factors influencing this industry.

\subsection{Important attractive items for sport tourism in province of Ardebil}

It is always an interesting idea to know which items absorb more people to this province. We have collected people's opinions on winter sports, water related sports, water treatment, traditional sports, domestic sports, rural sports, ecotourism, various championships, etc. The results of our survey yields $\chi^{2}=245.280$ with seven degrees of freedom and $\mathrm{p}$-value $=0.000$, which means the null hypothesis of having no influence of different sport activities on sport tourism was strongly rejected.

The frequency of the responses for winter sports, water related sports, water treatment, traditional sports, domestic sports, rural sports, ecotourism, various championships were 22, 2, 61, 1, 1, 2, 10 and 1, respectively. The Oi-Ei statistical test indicates that the survey people mainly are mainly interested in water treatment for traveling to this region. Note that the city of Sarein is the host of hot mineral water, which attracts many visitors to that region.

\subsection{The impact of having different festivals on attracting more sport tourists}

It is always an important question as to whether we can develop this industry by having more festivals on this region. This question is asked from the people who participated in our survey and the results strongly rejected the null hypothesis. In other words, 67 percent of the survey people believed that we can develop this industry by having more sport related activities. 


\subsection{The impact of having different non-seasonal festivals on attracting more sport tourists}

We repeated the previous question by asking the people as to whether non-seasonal sport activities could prompt sport tourism activities and the results of our survey strongly confirm the results of previous questions.

\subsection{The degree of familiarity of the survey people on attractive events}

We have requested our survey people to let us know on whether there was sufficient information from different media on attractive places of this province and most people believed there was not good awareness on informing people of these events.

In summary, we can conclude that sport tourism plays an important role on developing economies especially for developing countries where beautiful natural places are valuable treasures. The proposed model of this paper reveals that people are interested in tourist sport mainly because of the special advantages of this province, which makes it distinguishable from other provinces. The most important factor for tourism in this province is water treatment followed by beautiful mountain surrounding the province. People are also interested in visiting historical monuments of the province.

\section{Conclusion}

The present study has investigated different factors influencing sport tourism in one of the Iranian provinces. The proposed study designed a questionnaire consist of various questions in Likert based and distributed among 100 people who visited the province as tourist. The questions were analyzed using some statistical tests and the results were validated using Cronbach alpha. The results indicated that people were very much interested in water treatment and preferred to travel to use the existing mineral water resources for various reasons such as medication and pleasure. The results of this survey indicated that the province could promote sport tourism by providing more awareness using governmental mass media.

\section{Acknowledgment}

The authors would like to thank the anonymous referees for constructive comments on earlier version of this work.

\section{References}

Barker, R., Gledhill, A., Lydon, C., Miles, A., Mulligan, C., Saffery, G., Saipe, R., Sutton, L. \& Adam, M. ( 2007). BTEC National sport. $2^{\text {nd }}$ edition, Heineman Educational Publisher.

Cronbach, L. J. (1951). Coefficient alpha and the internal structure of tests. Psychometrika, 16(3), 297-334.

Devine, A. \& Devine, E. (2004). The politics of sport tourism in Northern Ireland. Journal of Sport Tourism, 9(2), 171-182.

Gammon, S. \& Robinson, T. (2003). Sport and tourism: A conceptual framework. Journal of Sport Tourism, 8(1), 21-26.

Gets, D. (1998). Trends, strategies, and issues in sport-event tourism. Sport Marketing Quarterly,7, 813.

Gibson, H. (2006). Sport tourism, concepts and theories. Taylor and Francis Group Ltd. 
Gibson, H.S.A., \& Yiannakis, A. (1998). Segmenting the sport tourist market: A life span perspective. Journal of Vacation Marketing, 4, 52-64.

Hamilton-Smith, E. (1993). Sport tourism as the celebration of subculture. Annals of Tourism Research, 25, 275-292.

Hall, C. (1992 ). Hallmark tourist events. Belhaven Press, London.

Kozak, M. (2004). Destination benchmarking: Concepts, Practices and operations. CABI publisher.

Kurtzman, J. (2005). Sport tourism categories. Journal of Sport Tourism, 10(1), 15-20.

Kurtzman, J. \& Zauhar, J. (2005). The emerging profession- sport tourism management. Journal of Sport Tourism, 10(1), 3-14.

Likert, R. (1932). A Technique for the Measurement of Attitudes. Archives of Psychology, 140, 155.

Pearce, P.L. (2009) Now that is funny Humour in Tourism Settings. Annals of Tourism Research, 36(4), 627-644.

Plog, S.C. (1991). Leisure travel: making a growth market . . again!. Willey and Sons, New York. Shank, D. M. ( 2005). Sport marketing. A Strategic perspective, USA.

World Tourism Organization. (1997). Tourism 2020 Vision: A New Forecast. Executive Summary, World tourism organization, Madrid.

Zhang, J. J., Pease, D.G., \& Hui, S. C. (1996). Value dimensions of professional sport as viewed by spectators. Journal of Sport and Social Issues, 20(1), 78-94. 